\title{
Destination Branding Through Semiotics Analysis of Video Wonderful Indonesia 2018 'The More You Feel, The More You Know'
}

\author{
Jessica Renanda \\ English Department, Faculty of Languages and Literature, Petra Christian University, Siwalankerto 121- \\ 131, Surabaya 60236, INDONESIA \\ Email: m11416043@john.petra.ac.id
}

\begin{abstract}
In this study, by using the destination brand benefit pyramid and semiotics theories, the writer aimed to analyze the destination branding of Indonesia's Tourism through semiotics analysis in visual and verbal expressions of video Wonderful Indonesia 2018 'The More You Feel The More You Know'. In this video, Indonesia's tourism 2018 is highlighting three main destinations: East Nusa Tenggara, Bali and Yogyakarta. The writer also analyzed the rational benefits, emotional benefits, destination brand values (personality) and the brand essence of Indonesia's tourism: Wonderful Indonesia. The writer uses qualitative content analysis as approach of study. As the conclusion, the writer found that visiting Indonesia as the biggest archipelago of the world is more than just a leisure activities, but is about a journey to discover and to feel the real essence of Indonesia - a wonderful country, not just because of its natural wonders that are exist nowhere else in the world, but also because of the cultural traditions that are full of moral values which are inherited and ingrained from generation to generation as the identity as well as the characters of Indonesian people.
\end{abstract}

Keywords: Destination branding, destination brand benefits, verbal and visual expressions.

\section{INTRODUCTION}

In 2018, Indonesia has been acknowledged as the ninth fastest growing tourism sector in the world, number three in Asia, and number one in Southeast Asia (Dea, 2018); thus, to encourage economic development, tourism sector in Indonesia should be promoted through destination branding. Destination branding is the set of marketing activities (1) that support the creation of a name, symbol, logo, word mark or other graphic that readily identifies and differentiates a destination; (2) that consistently convey the expectation of a memorable travel experience; that (3) serve to consolidate and reinforce the emotional connection between the visitor and the destination; and that (4) reduce consumer search costs and perceived risk (Blain, Levy \& Ritchie, 2005). Through destination branding, Indonesia can attract more visitors; which means, there will be a high opportunity to raise the GDP income. Destination branding should reflect the essence (heart, soul, and spirit) of the benefits and the experiences (functional and emotional) that guests expect when visiting a destination (Knapp, 2008). According to Morgan, Pritchard \& Pride in Destination Branding: Creating The Unique Destination Proposition (2004), the destination brand benefit pyramid can be used to craft the essence of a destination. It consists of five levels: a.) attributes, which is the tangible features or the destination itself, b) rational benefits, which described the experiences that tourist can have when visiting the destination, c) emotional benefits, referred to what tourists felt after having the experiences, d) brand values (personality)how tourists personified the destination, and e) brand essence -heart and soul of a destination or the essential nature of a destination.

An advertisement video can be a suitable alternative to promote a destination because it captured the audiovisual sensory of visitors, which then can affect their emotion; thus, in 2018, Indonesia's 
Tourism launched a tourism advertisement video entitled 'The More You Feel, The More You Know', in which the video promoted natural landscapes and cultural heritage of Yogyakarta, Bali, and East Nusa Tenggara. The writer decided to analyze the video of Wonderful Indonesia 2018 "The More You Feel, The More You Know" because it has delivered Indonesia to achieve an "Honorary Award" in The XIV International Tourism Film Festival (ITFF), which was held in Bulgaria, on April 19, 2018, and was participated by 49 films from various countries. Furthermore, this video invited positive reviews from foreigners in YouTube.

In making the advertisement video, signs, which include short message and images play an important role in destination branding. These signs, analyzable through semiotic theory, attempt to capture the attention of potential visitors through engaging with the observer's ability to recognize and receive such patterns and sub-textual information (Golinvaux \& Ioannis, 2017). However, as declared by Peirce, "Nothing is a sign unless it is interpreted as a sign"; therefore, these signs need to be interpreted (giving meanings) as 'signifying' something - referring to or standing for something other than itself. A linguist called Ferdinand de Saussure who was also a founding father of semiotics (study of signs), defined a process of signification in Semiotics: The Basics (Chandler, 2007, p.16) as being composed of a signifier - the form which the sign takes, and a signified - the concept it represents. Process of signification is defined as the relationship between the signifier and the signified. Process of signification itself consists of two levels of meaning; denotation and connotation. The first level is denotation, which is the literal meaning, or in which dictionary defines it. It means consumers simply identify a sign exactly as what they see or hear only. The next level of signification is connotation, which deals with mental association of consumers towards signs. It could be associated to ideological or socio-cultural background knowledge of consumers. In other words, signification process is an effective way to understand the hidden meaning behind the sign. Therefore, in this research, the writer aim to analyze the images of Indonesia's Tourism constructed and represented through semiotics analysis in destination branding of video Wonderful Indonesia 2018 'The More You Feel, The More You Know'.

\section{THEORECTICAL FRAMEWORK}

In this study, the writer uses the destination branding theory, including destination brand benefit pyramid by Morgan, N., Pritchard, A., \& Pride, R. (2004). To analyze meanings behind the advertisement, the writer uses the process of signification and the levels of signification (denotation and connotation). Moreover, the writer also included Peirce's models of sign, such as index, icon, and symbols.

\section{Destination Branding and Destination Brand Benefit Pyramid}

Destination branding is all about developing a rich, relevant brand personality: it has both a head and a heart: its head refers to the logical brand features, while its heart refers to its emotional benefits and associations (Morgan, et. al, 2004, p. 70). Meanwhile, destination brand benefit pyramid conveys the consumer's relationship with a destination and is frequently established during the consumer research process where consumers are usually asked to describe what features a destination offers and what the place means to them. The destination brand benefit pyramid can be instrumental in helping to distil the essence of a destination brand's advertising proposition (Morgan et.al, 2004, p.70). According to Morgan et.al (2004), there are five levels of destination brand benefit pyramid:

First level: Destination brand attributes

Attributes refer to the services or goods that the brand provides, or the tangible features of a destination. Countries are often showcase their history, culture and beautiful scenery, but many destinations have these attributes; therefore, it is important to find something unique about the 
destination, in which other countries want and may be able to copy, but they cannot surpass or usurp. For instance, other world cities can claim to be romantic or spiritual, but only Rome is The Eternal City; it had it first and no other place can claim that epithet (Morgan, et.al, 2004, p.65). At this stage, Indonesia's tourism in 2018 promoted Komodo Island and Bena Village in East Nusa Tenggara, Jatiluwih Rice Terraces at Bali, and Batik.

Second level: Functional (rational) benefits

Functional (rational) benefits refer to experiences that tourist results from the destination's features like memorable experiences, travel for leisure and travel as fashion accessories. Travel for leisure is increasingly permeating the discourse of everyday life, but remains a highly involving experience, extensively planned, excitedly anticipated and fondly remembered (Morgan, et.al, 2004, p.4). Conceptual model of leisure activity distinguishes two kinds of leisure. Serious leisure includes activities (e.g., amateur sports participation) characterized by long-term commitments to developing skills through overcoming challenges (e.g., learning difficult skills), and casual leisure activities, which require little skill and are considered pleasurable; for instance, drinking coffee while enjoying sunset or hanging out with friends (Stebbins, 1997). Another rational benefit of a destination is travel as 'fashion accessories'. The World Tourism Organization suggesting that the twenty-first century will see the emergence of tourism destinations as fashion accessories (Morgan, et.al, 2004, p. 4). Tourists seek destination that fulfills their needs, wants and desires for new tastes in garments, and the overall experience of the destination's culture that reflects its creativity, innovation and intricate tapestry of skills and knowledge of the country. The tourists are made to actively participate in the destination's fashion experience.

Third level: Emotional benefits

Emotional benefits refer to the customer's feelings after visiting a destination. It is the emotional value resulting from consumer's association of a destination with a country (Morgan, et. al, 2004, p. 41). As an example, what the tourists feel after visiting England is 'fulfilled by experiencing the quaint culture, relaxed by the harmonious countryside and soothed by the outdoors.

Fourth level: Destination's Values (Personality)

Brand values (personality) can be formed through tourist's direct or indirect contact with a destination. A destination brand's personality has both a head and a heart: its head refers to the logical brand features, while its heart refers to its emotional benefits and associations (Morgan, et. al, 2004, p. 70). Destination personality traits can be associated with a destination in a direct way, through people in a community, citizens in a city, tourism attractions, or through tourist's imagery, defined by a set of human characteristics associated with the typical visitors of a destination.

Fifth level: Destination Brand Essence

Destination brand essence captures the core spirit of a destination, both the functional and the emotional benefits. In building a meaningful destination brand, the essence is to create an emotional relationship between the destination and potential visitors. The long-term brand essence should not be confused with the campaign tagline. The branding activities concentrate on conveying the essence or the spirit of the destination.

\section{Process of Signification}

Semiotics, developed by a Swiss linguist, Ferdinand de Saussure, is a study of sign. Semiotics seeks to analyze the signs, including images, sounds, patterns, etc. In semiotics, meaning of signs can be interpreted by using the process of signification. The sign is defined by Saussure as the 
union of a signifier and a signified, a sound image and a concept. The signifier is now commonly interpreted as the material (or physical) form of the sign - it is something which can be seen, heard, touched, smelt or tasted (Chandler, 2007, p.15). On the other side, signified is a concept which is suggested by the signifier. Saussure emphasized that the relationship between the sound (or shape) of a spoken (or written) word and its meaning is 'arbitrary'; which means, there is no natural and logical relationship of why a signifier is connected to the signified (concept). For instance, English speaking-society agreed upon the word 'flower' as plant, but in Indonesia, the word 'flower' is used for a beautiful maid of a village. The sign maker selects a signifier for its aptness to the expression of particular meaning

\section{Denotation \& Connotation}

As Chandler (2007) cited Roland Barthes' theory, the process of signification involves two levels, which are the denotation and connotation. The first level of signification is denotation. Denotation is described as the definitional, 'literal', 'obvious' or 'commonsense' meaning of a sign. In this level, sign consists of signifier and signified. Connotation is the second level of signification, which refers to the socio-cultural and personal associations (ideological, emotional, and so on) of the sign. Connotation uses the denotative sign (signifier and signified) as its signifier and link it up to an additional signified. Connotation is a sign which derives from the signifier of a denotative sign; therefore, denotation leads to a chain of connotations.

\section{Peirce's Model of Sign}

Charles Sanders Peirce in the late $19^{\text {th }}$ century differentiated three kinds of signs: icon, symbol and index (Chandler, 2007, p.36-37). Icon is perceived as resembling or imitating the signified (recognizably looking, or smelling sounding, feeling, tasting or smelling like it)- being similar in possessing some of its qualities, e.g. a portrait, a cartoon, onomatopoeia, imitative gestures, etc.

In symbol, the signifier does not resemble the signified but which is fundamentally arbitrary or purely conventional - so that the relationship must be learnt. In symbols, in space and time between the sound of the word, no logical meaning between it and the object; for instance, numbers, Morse code, traffic lights national flags, bald Eagle for USA, etc.

Index emphasizes that the signifier is not arbitrary but is directly connected in some way (physically or causally) to the signified, in which this link can be observed or inferred. Index does not resemble the object or concept being represented; however, it resembles something that implies the object or concept and it defined by sensory features that correlates with certain meaning. For instance, natural signs (smoke, thunder, footprints, echoes, non-synthetic odors or flavors), medical symptoms (pain, a rash, pulse-rate), measuring instruments (weathercock, thermometer), signals (a knock on a door, a phone ringing), etc.

\section{RESEARCH METHOD}

The research was conducted by using qualitative content analysis since the research was intended to find the destination brand image of Indonesia's tourism through process of signification in visual and verbal expressions of the video. This approach is effective for the video analysis because the purpose of qualitative content analysis is to understand the meaning of the text as interaction between the preconceptions of the reader and the intentions of the text producer (Mayring, 2014, p.10-13). Qualitative content analysis takes the structure and meaning of the material to be analyzed (i.e. the text) as its starting point and the meaning of symbols must also be discussed; one cannot simply start from the lexical meaning of terms but should also take into account their context, their circumstances of origin and the intentions behind them. 
The source of data for this research is Wonderful Indonesia's advertisement video 2018 entitled 'The More You Feel, The More You Know', which was uploaded on YouTube, on August $22^{\text {nd }}$ 2018. The data was limited into visual and verbal expressions. For the visual expressions, the writer selected 16 scenes from the video that represent each level of destination brand benefits of Indonesia's Tourism, while the verbal expression would be in the form of the song lyrics 'What a Wonderful World' by Louis Armstrong (1967) that support the visual expressions of the video. The writer searched the literal meaning (denotation) of the keywords of the lyric in the Oxford Advanced Learners Dictionary as the source of definition.

\section{FINDINGS AND DISCUSSIONS}

The first level of destination brand benefit pyramid consists of the description of attributes (features) presented in video The More You Feel The More You Know: Komodo National Park, Bena Village, Jatiluwih Rice Terraces in Bali, and Batik from Yogyakarta. These attributes are the icons of each destination. Referring to C.S. Peirce's models of sign, an icon is the representation of an object or idea that is clearly recognizable looking by the audience (Chandler, 2007, p.27); in other words, when talking about a destination, people will soon link it to some particular products, natural resources, cultural heritage, etc. When talking about East Nusa Tenggara, tourists often link it to Komodo National Park, which is famous for its endemic animal that exist nowhere else in the world- Komodo Dragon. Komodo National Park is famous because it has been recognized by UNESCO (United Nations of Educational, Scientific and Cultural Organization) as a world heritage site in 2012 as well as a global conservation priority area (UNESCO World Heritage Centre, n.d); therefore, Komodo National Park is considered as the icon of natural wonder of Indonesia in East Nusa Tenggara.

Another icon of East Nusa Tenggara presented in video The More You Feel, The More You Know is Bena Village. As an ancient megalithic village in East Nusa Tenggara that has been nominated as a world's heritage site in 1995, Bena village is well-known for the unique shape of the village, which is looked like a boat. Bena Village is also famous for its traditional houses, 'ngadhu' and 'bhaga'. 'Ngadhu' is described as a wooden pole carved with animal motifs. 'Ngadhu' is the representation of male ancestors, while 'bhaga' is described as a miniature house next to 'ngadhu', which is believed as the representation of female ancestors of Bena. For Bena's villagers, both houses represented the kinship between their ancestors and their generation.

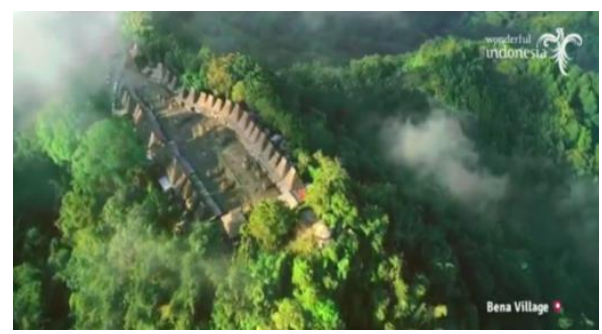

The second tourism destination projected in the video is The Jatiluwih Rice Terraces in Bali. The Jatiluwih Rice Terraces as the best representation of Bali's outstanding rice fields and Subak System presented a heavenly green-scenery landscapes have been inscribed as a UNESCO's World Heritage Site in June 2012 (UNESCO World Heritage Center, n.d). As a world heritage, Jatiluwih's rice terraces can be categorized as the icon of green natural landscape of Indonesia because when talking about Indonesia, people often link it to Bali's beautiful natural green scenery, which is represented by Jatiluwih's rice terraces, and even called as the Green Carpet. 


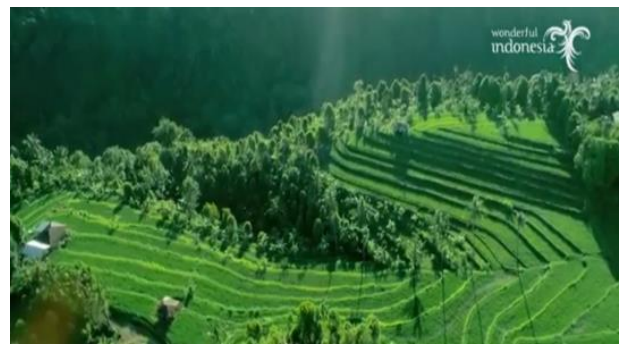

The third tourism destination projected in the video is Yogyakarta. Yogyakarta is often linked to its cultural heritage, including 'Batik'. As an iconic heritage from Indonesia which has been recognized by UNESCO Intangible Cultural Heritage, batik is popular and well-known internationally for its unique techniques. Batik came from ancient word "(a)mba-tik" which means making or writing range of dots on cloth (Waworuntu,n.d). It is made by decorating cloth by using wax and dye, which Indonesian call as 'mencanting'. 'Mencanting' is one of the most 'looking for' activity for visitors when coming to Indonesia.

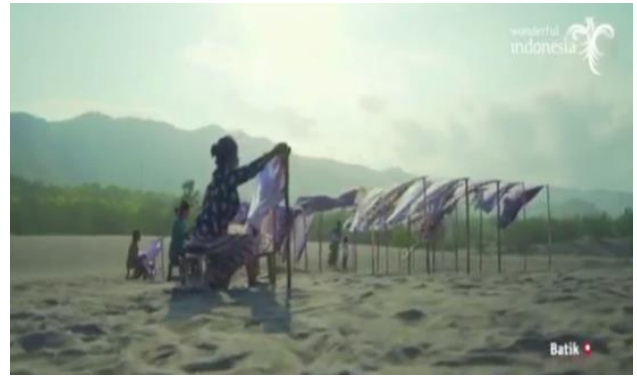

Referring to Peirce's models of sign (Chandler, 2007, p.27), in symbol, the relationship between signifier and signified must be learnt since the signifier does not resemble the signified but which is fundamentally arbitrary or purely conventional; therefore, 'Batik' is not only presented as the icon of Yogyakarta, but it can also be presented as the symbol of cultural heritage of Indonesia because 'batik' is not only about decorating cloth, but it is also intertwined with the cultural identity of Indonesian people and through the symbolic meanings of its colors and designs, expresses their creativity and spirituality (UNESCO Intangible Cultural Heritage, n.d).

The second level of destination brand benefit pyramid is the rational benefits. It consists of experiences that tourist results from the destination's attributes (features): memorable experiences, travel for leisure and travel as fashion accessories (Morgan et.al, 20014, p. 4). Those experiences can be analyzed through the pictures and words as semiotics resources of the video. Based on Saussure's levels of signification, the first scene denotatively portrayed the image of a woman closing her eyes while holding a shell. Based on a study held by University of Surrey, closing eyes had much higher memory recall (Readhead, 2015); thus, the woman closes her eyes signified that she is getting into a deeper feelings and recalling fondly memories. The big white shell is associated as something precious and expensive. It is because as a collectible item, the price of the shell can be ranged up to million rupiahs depend on the types and sizes (Saraswati, 2010). 


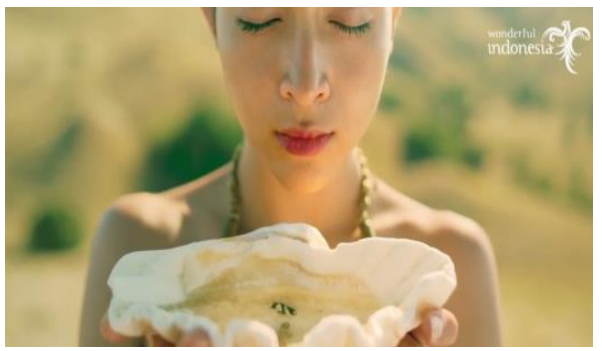

The way the woman holds the shell with two hands carefully is also supported the idea that she is holding the shell not just as an ordinary thing, but as something precious, expensive and fragile. On the other side, the water inside the shell signified the reflection of memories (Davies, 2011); thus, the big white shell with water in it connoted treasurable memories, which refers to her experiences in Indonesia. A little smile on her face indicates satisfaction, happy feelings, as if visiting Indonesia was a precious memory that she will fondly remembered.

Those 'experiences that are fondly remembered' are portrayed through the sequence of the woman's memories during in Indonesia, and one of them is the experience of family adventure to Komodo Island, East Nusa Tenggara. On the first level of signification, the next scene portrayed an image of a family watching a big Komodo dragon.

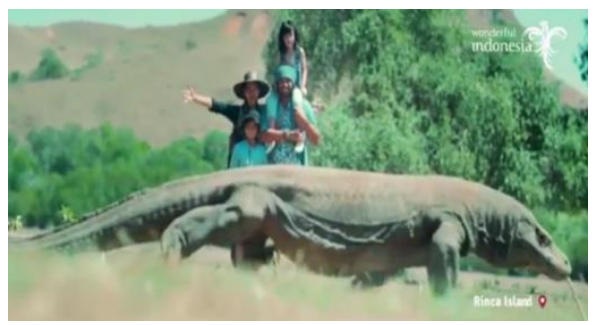

For tourists, Komodo Dragon is just a population of large lizards that are only exist in Indonesia; but for villagers in Komodo Island, Komodo is more than just a lizard. The villagers in Komodo Island also believed that they come from the same ancestor as the Komodo (Agmasari, 2019); it means, Komodo has become a totem that protects family in Komodo Island; and thus, Komodo is can be considered as the symbol of local wisdom in Komodo Island; thus, Komodo that walked in front of the family in figure 4.6 connoted a meaning that by visiting Wonderful Indonesia, tourists can experience a new adventure together with the family and community of the local people.

The 'experiences that are fondly remembered' is also portrayed through the togetherness (kinship) with the local people. Figure 4.7 (a) showed a tourist boy played 'gasing kayu' with some local children in Bena village. Playing 'gasing' represents the togetherness because it is a traditional game played in a group of people. For Indonesian people, 'gasing kayu' connotes the philosophy of balance. A 'gasing' that is able to rotate for a long time is the one which has perfect balance on all sides. Indonesian people believed that a good life is also about maintaining the balance between physical, mental and social life; especially the social life. Indonesia as a diverse country with thousand cultures and languages need to maintain a strong bond to keep the unity. They like to live collectively and working together as a nation; therefore, the term 'gotong-royong' (mutual cooperation) has become the foundation of Indonesian people. 


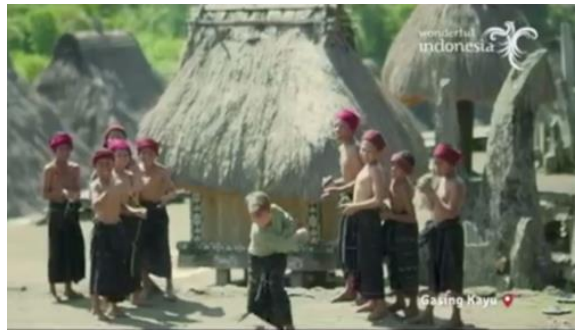

Even the designs of Bena's traditional houses are also reflecting the values of togetherness. Figure 4.7 (a) is not only displayed the children but also portrayed the image of ngadhu and bhaga - the monument of Bena's ancestors. 'Ngadhu' is look like an umbrella made of reeds with a carved wooden pole and it represented male ancestors. On the other side, 'bhaga' is shaped like a miniature of traditional houses in Bena with thatched roof. 'Bhaga' represents female ancestors of Bena, and it is always built right behind 'Ngadhu', and every clan in Bena Village has 'Ngadhu' and 'Bhaga' (Jayanti, 2012). Both of these buildings represent the values of 'living together' between men and women in Bena. With the existence of 'Ngadhu' and 'Bhaga' as the representation of Bena's ancestors and villagers between the children in figure 4.6 (a), it is seemed as if the tourist boy is not only enjoying togetherness with the children, but also accompanied by the whole community of the village; thus, by visiting Wonderful Indonesia, tourists can learn and experience the meaning of togetherness in Bena Village.

The second rational benefit of Wonderful Indonesia is 'travel for leisure'. On the first level of signification, the image of a man holding a cup of coffee while enjoying the quiet sea of Gili Lawa Darat, Komodo National Park- East Nusa Tenggara with his sitting position (slightly open legs and one leg flopped down sideways) indicates relax and comfortable position (Lewis, 2012, p.169).

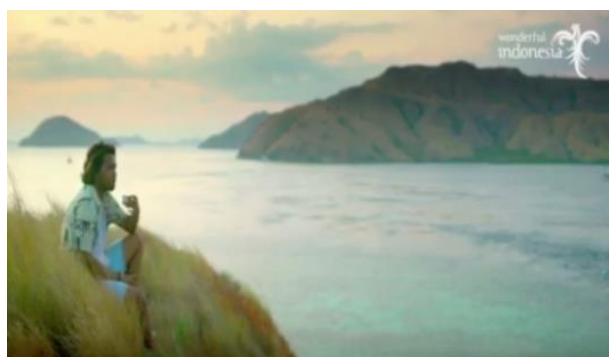

The quiet sea signified the calm mind, dynamic emotions and inner peace, while the hidden depths of the sea stand for the indescribable and deep thoughts, feelings, emotions that are not visible on the surface (Steiner, 1911). As its connotative meaning, the man's gaze that lead to the sea implied a meaning that he is dealing with his own sub consciousness and going deeper into his own emotions and mind to find insights and tranquility; thus, through this scene, Indonesia's Tourism wanted to convey a message that by visiting Indonesia, tourists can experience leisure activity like enjoying tranquility on a relaxing natural landscape.

Another leisure activity that tourists can experience in Indonesia is surfing. Surfing is categorized as a serious leisure activity because it develops skill through overcoming challenges, which is to keep the body balanced on the water. The blue turquoise color of the sea is associated with serenity, balance and clarity of mind. It can also be associated to high self-esteem, introspection and emotional control (Przybyla, n.d); meanwhile, the waves connoted challenges or pressures of life. 


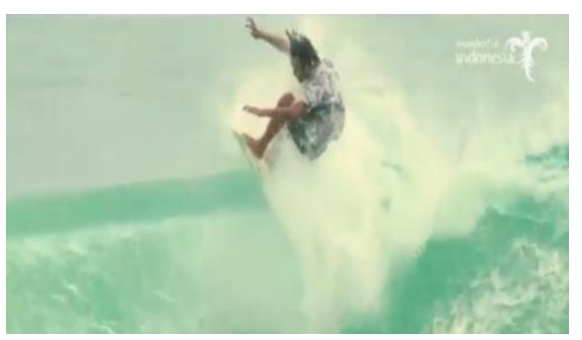

Surfing is a therapy because it needs high concentration and stability to ride the waves and thus, it allowed people to be distracted from things that might be bothering, to get a shift of perspective (Willis, 2018). Thus, on the second level of signification, the man surfed the waves on a turquoise sea connoted a meaning that he is encouraging himself to overcome fears, anxieties and pressures of life and bring himself into his own state of being. Through this scene, Indonesia's Tourism wanted to convey a message that by visiting Indonesia, tourists experience leisure activities, not just enjoying tranquility on a relaxing natural landscape, but also by having a mental therapy through watersport that can triggered adrenaline to overcome anxiety.

The third rational benefit that visitors may experience in Indonesia is travel as fashion accessories, which is represented through the making process of batik.
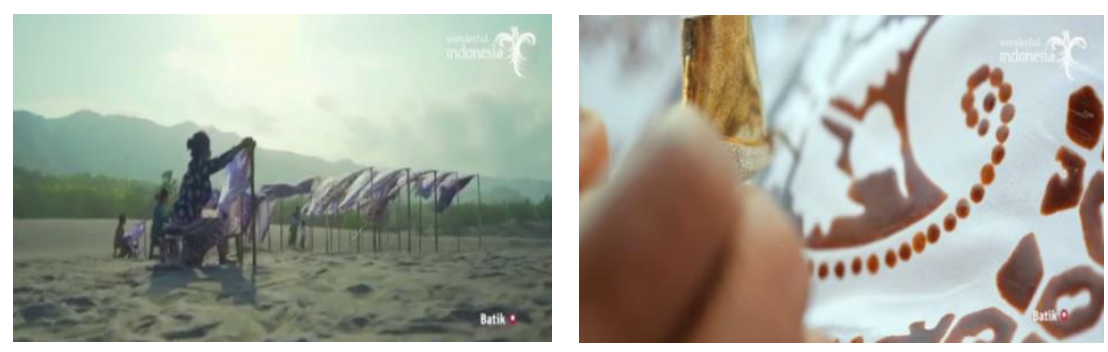

On the first level of signification, mencanting is an art of decorating cloth by using wax and dye. On the second level of signification, the process of making batik that needs perseverance and tenacity to finish such complicated patterns is the representation of the characters ingrained in Indonesian people. Thus, Batik is not only presented as a rational benefit of Wonderful Indonesia, which is travel as fashion accessories, but also as the representation of the spirit of Indonesian people.

The third level of destination brand benefit pyramid is the emotional benefits, which refers to the visitor's feelings after visiting Indonesia. Through the video, Indonesia's Tourism in 2018 wanted to convey message that by visiting Indonesia, tourists will experience feeling proud of being a part of an important heritage of a country. Most tourists are appreciate and feeling proud to wear Batik, not only because of its status as Indonesia's cultural heritage that has been acknowledged as a world's cultural heritage, but also because of its beauty and the complexity during the making process. On the first level of signification, the woman in the scene is portrayed like a queen, with a bright yellow Batik as her robe. She sits at the front of mirrors on a river; her head is slightly tilted and her chest is a little expanded. According to Rockwell (2004), the expanded chest with slightly tilted head signified the sense of pride. The expanded posture created the impression of largeness, and the slight head tilt conveyed superiority. Connotatively, the expanded chest with slightly tilted head connoted a feeling of being superior and pride of wearing Batik. 


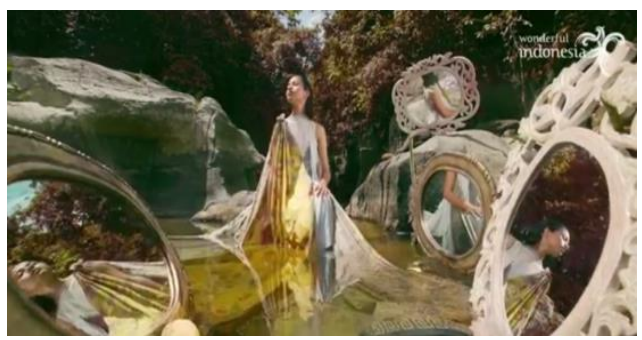

The second emotional benefit that visitors may experience in Indonesia is feeling relaxed and peaceful. There is a scene portraying an image of a tourist is having a natural spa in Bali.. Referring to Peirce's model of sign, icon is perceived as resembling or imitating the signified; therefore, closing eyes with arms stretched around body can be considered the icon of feeling peaceful and relaxed because it imitates the gesture of feeling peaceful (Widiastuti \& Nurtanzila, 2018). The woman felt peaceful and relaxed of being in a soothing nature of Indonesia. Soothing nature is signified with the green leaves upon her head and the calm water that reflects the trees around the pool.

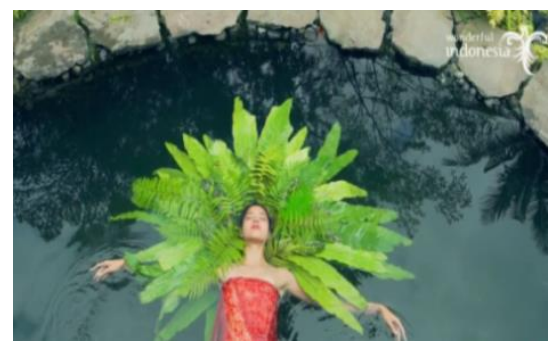

Woman related to nature; she incarnates it: vale of blood, open rose, siren, the curve of a hill, she represents to man the fertile soil, the sap, the material beauty and soul of the world (Zimmerman, 2011, p.178), and also connected with the role of women to comfort and to nurture; thus, the woman in this scene is represented as the goddess of nature (Mother Earth). It is also supported with the green leaves upon her head and water surrounded her that signified nature (The Earth). On the other side, the woman's white skin combined with the red batik she wore seemed like the colors of Indonesian national flag, which is consist of red and white (Sang Merah Putih).); thus, the woman in red batik cloth and leaves upon her head connoted a meaning that as The Mother Earth, Indonesia is well-known for its soothing nature that can make people feel peaceful and relaxed.

Another emotional benefit that visitors can experience in Indonesia is being inspired to value cultural diversity. On the first level of signification, the scene displayed a tourist wearing Batik together with some local women who are also wearing Batik.

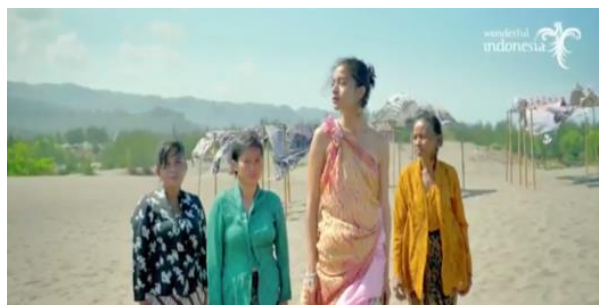

Meanwhile, on the second level of signification, it connoted a meaning that wearing batik is universal; everyone can wear Batik despite of their cultural differences, languages or races. Batik is a symbiosis or a combination of communal values that represent high value local culture in a 
particular community. It can be a cross-cultural medium, because its existence represents the diversity of traditional arts as well as various aspects of communal society in an area (Suleman, 2017); thus, by wearing 'Batik', the tourist appreciates being a part of and valuing the cultural diversity of Indonesia.

The fourth level of destination brand benefit is destination's personality. The first destination personality of Wonderful Indonesia 2018 is wonderfully beautiful. It can be seen from the opening scene of the video that showed thick fogs covers the screen and disappears slowly, portraying the image of a golden sunrise at Gili Lawa Darat, East Nusa Tenggara on a sparkling ocean. According to C.S Peirce's models of sign, an 'index' can be understood as the sensory features that are connected in some way (physically or causally) to the signified (Chandler, 2007, p.27); thus, the fogs that disappeared slowly is an index that signified a great revelation.

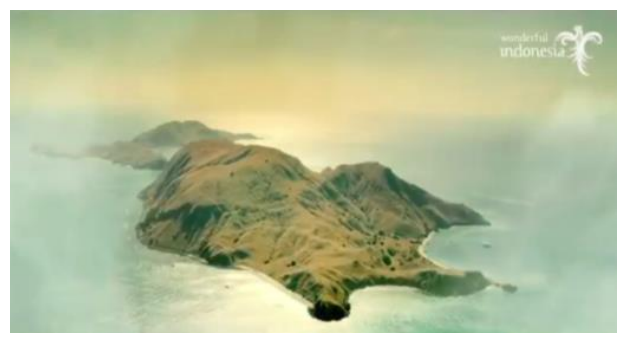

It means, something wonderful is being revealed; in this case the wonders of Indonesia. On the other side, when the fogs faded away, the scene displayed the image of golden sunrise in Gili Lawa Darat, East Nusa Tenggara. Referring to Saussure's levels of signification, the secene connoted the divinity and the majestic of natural wonders of Indonesia. It is divine since the golden sunrise is represented the divine source (Rivers, 2019), while divinity is often associated to heaven; thus, it connoted a meaning that Indonesia is the 'heaven on earth'. The sparkling ocean connoted brightness, life and beauty (Carlson, 1964, p.15). It seems as if the land on the sparkling ocean is a glamorous sparkling jewel- a precious stone or gem. The scenery of Gili Lawa Darat in the middle of sparkling ocean connoted a meaning that the natural landscape of Indonesia is as beautiful as precious as jewel, even called the Jewel of Equator.

Indonesia is also blessed with beautiful green nature. On the first level of signification, the next scene portrayed the green Jatiluwih Rice Terraces under the rays of sun. This scene is supported by the first line of the background song 'I see trees and green'. Rays of sun is signified as the completion of the Great Work (Cooper, 1978), while the 'green' signified peace and happiness which can stabilize the mind (Verma, 2014); thus, green rice field under the rays of sun connoted a meaning that the beauty of Indonesia's natural wonder is projected as if the tourists is looking at a masterpiece of The Creator, that it makes people can feel peaceful and calm.

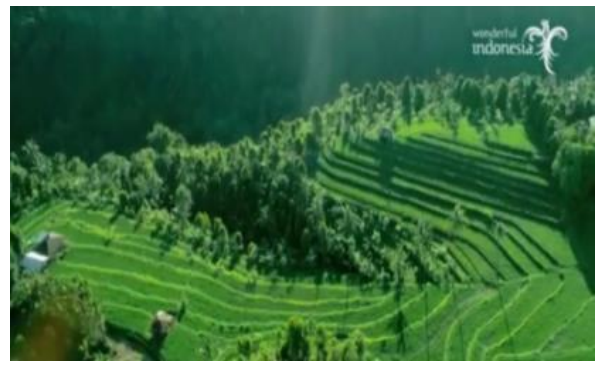

Therefore, the personality of Wonderful Indonesia is presented as a wonderfully beautiful country, where visitors can experience a 'heaven on earth'- divine and soothing natural landscapes. 
The second personality trait of Indonesia is often linked to its friendly people. It can be seen from their warmth welcome to the visitors. On the first level of signification, Figure 4.14 showed the figure of a foreign tourist girl shaking hand with a local boy in Bena Village, Nusa Tenggara. This scene is supported by the next lyric 'I see friends shaking hands saying how do you do'.

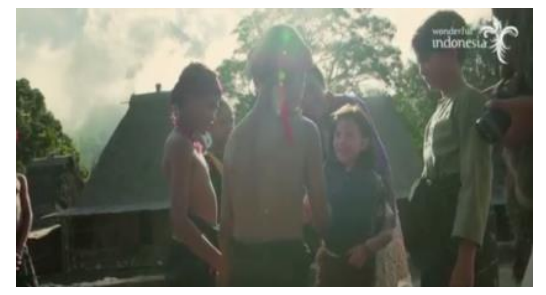

Shaking hands is the symbol of peace and unity, in which it conveys a message of warmth and friendliness (Schroeder, et. al, p.6). It is a gesture that signified an intention to make a friend, an act of friendship (Harris, 1998, p.213); meanwhile, according to Oxford Learner's Dictionary (2019), the word 'friend' means person who will help and support. Thus, in the second level of signification, shaking hands connoted a meaning that Indonesians are warmth and friendly people who are likely to welcome and support the visitors with open hands.

Destination brand essence is the core spirit of a destination that makes it different from other destinations. The last scene portrayed the image of a tourist is lying on the hammock right on the middle of blue sea. In connotative layer, the blue color of the sea connotes 'heaven' (Thompson, 2002). Being surrounded by blue color can give calming effect to people. Meanwhile, her left hand sustains her head and her eyes straight to the sea, as if she is thinking about somethingabout what a wonderful world Indonesia is; which is also supported by the end of the song lyric " and I think to myself, what a wonderful world'. According to Oxford Learner's Dictionary (2019), the word 'wonderful' means very good, pleasant and enjoyable. Another definition is admiration. Thus, the tourist that lying on the hammock surrounded by blue sea connoted meaning that tourists admire and enjoy the beauty of Indonesia's natural wonders.

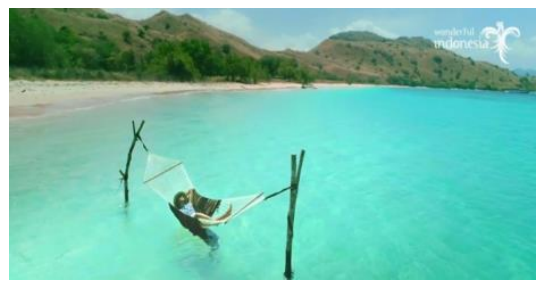

In this scene, the tourist is lying on a woven fabric upon the hammock. For East Nusa Tenggara people, a woven fabric is considered as a humanitarian communication media that is involved in the intertwining of East Nusa Tenggara community relations (Sara, 2010). Moreover, a woven fabric is also symbolizes the unity of diversity of Indonesia (Bhinneka Tunggal Ika), because in making a woven fabric because although woven clothes in Indonesia have different patterns, but the weaving technique unifies those differences (Taqwa, 2015, p.13). Just like a woven cloth that looked beautiful after combining the different yarns, Indonesia which consists of different races, cultures, religions and languages can also create beautiful harmony though the unity that is reflected under the slogan 'Bhinneka Tunggal Ika'. Strengthening Bhinneka Tunggal Ika will be needed to reinforce the identity of Indonesia (Baihaki, 2017). Figure 4.15 connoted a meaning that Indonesia is a wonderful country not only because of its beautiful natural landscape, but also because of the harmony and unity of the people that is reflected through its cultural heritage under the slogan 'Bhinneka Tunggal Ika' (unity in diversity); which is something that is not easily achieved and maintained by other countries. Thus, through the video 'The More You Feel The 
More You Know', Indonesia's Tourism wanted to emphasize the destination essence of Indonesia as 'Wonderful Indonesia'.

\section{CONCLUSION}

By analyzing the destination branding through semiotics analysis of Indonesia's tourism, it can be seen that visiting Indonesia as the biggest archipelago of the world is more than just a leisure activities, but is about a journey to discover and to feel the real essence of Indonesia - a wonderful country, not just because of its natural wonders that exist nowhere else in the world, but also because of the cultural traditions that are full of moral values which are inherited and ingrained from generation to generation as the identity as well as the characters of Indonesian people. Moreover, by using Peirce's models of sign to analyze video Wonderful Indonesia 2018 'The More You Feel, The More You Know', the writer found that Indonesia is the icon of natural wonders, an index of a heavenly earth, and symbols of cultural heritage and 'unity in diversity'. In short, the image of Wonderful Indonesia is shaped by the verbal and visual expressions of the video. Those words are visualized into pictures to make the advertisement more alive and more persuasive to attract the tourists. In other words, by understanding the meaning behind verbal and visual expressions of a tourism advertisement video, visitors can understand the core values and brand promises of a destination. In this case, Indonesia's tourism is portrayed as a wonderful country with beautiful natural resources and cultural heritages wrapped in unity in diversity.

\section{REFERENCES}

Agmasari,S. (2019). Cerita orang Pulau Komodo yang percaya satu leluhur dengan komodo. Kompas.com. Retrieved from https://travel.kompas.com/read/2019 /10/06/140000927/cerita-orang-pulau-komodo-yang-percaya-satu-leluhur-dengankomodo

Baihaki, E.S (2017). Strengthening Bhinneka Tunggal Ika as an identity and unifier of the nation: realizing a peaceful Islam and statehood harmonization. Retrieved from http://journal.stainkudus.ac.id/index.php/Addin/article/view/1965

Blain, C., Levy, S.E., \& Ritchie, J.R.B. (2005). Destination branding: Insights and practices from destination management organizations. Journal of Travel Research. 43(4), 328338.

Carlson, Ruth Kearney. (1964). "Sparkling and Spinning Words." Elementary English, 41(1). Retrieved from www.jstor.org/stable/41385583.

Chandler, D. (2007). Semiotics: the Basics (2nd ed.).London: Routledge

Dunning, J.D. (2011). Structure and Memory in Water. ResearchGate. Retrieved from https://www.researchgate.net./publication/228611683_Structure_and_Memory_in_Wat er

Dea, A. (2018, December 23). Kemajuan pariwisata Indonesia, penyumbang devisa terbesar Indonesia. Goodnews from Indonesia. Retrieved from https://www.goodnews fromindonesia.id/2018/12/23/kemajuan- pariwisata-indonesia-penyumbang-devisaterbesar-indonesia

Dimurlo, L. (n.d). Sun symbol meanings. Sunsigns.org. Retrieved from https://www.sunsigns.org/sun-symbol-meanings/

Golinvaux, A., Evagelou, I. (2017). The role of semiotics in Tourism Destination Branding through social media: the case of Switzerland. Journal of Tourism Research, 16(150). Retrieved from http://jotr.eu/index.php/volume16/150-the-role-of-semiotics-in- tourism-destinationbranding-through-social-media-the-case-of-switzerland

Harris, J. C. (1998). Developmental neuropsychiatry: fundamentals. New York: Oxford University Press, Inc. 
Cooper, J.C. (1978). An illustrated encyclopedia of traditional symbols. Thames and Hudson: London.

Jayanti, I.G.N. (2012). Religious system in indigenous communities of Bena Village.

Widyareset, 15(01). Retrieved from widyariset.pusbindiklat.lipi.go.id

Knapp, D.E. (2008). The brandpromise: how Costo, Ketel One, Make-A- Wish, Tourism Vancouver, and other leading brands make and keep the promise that guarantees success!. United States of America: Mc GrawHill.

Lewis, H. (2012). Body language: A guide for professionals (3rd ed.). India: SAGE Publications

Morgan, N., Pritchard, A., \& Pride, R. (2004). Destination branding: Creating the unique destination proposition ( $2^{\text {nd }}$ ed.). Oxford [England: Elsevier Butterworth-Heinemann

Myring, P (2014). Qualitative content analysis. Retrieved from http://files.qualitativecontentanalysis.aau.at/20000007582241831d6/Mayring(2014)Qua litativeContentAnalysis.pdf

Oxford Advanced Learner's Dictionary. (2015). Oxford: Oxford University Press.

Przybyla, D. (n.d). Turquoise color psychology and meaning. Colorpsychology. Retrieved from https://www.colorpsychology.org/turquoise/\#comments

Readhead, H. (2015, January 15). Trying to remember something? Just close your eyes, says science. Metro.co. $u k$. Retrieved from https://metro.co.uk/2015/01/17/tryingto-remember-something-just- close-your- eyes-says-science-5025795/

Rivers, M. (2019, December 2). The spiritual symbolism of the sun.Bahaiteachings.org. Retrieved from https://bahaiteachings.org/the-spiritual-symbolism-of-the-sun

Rockwell, S. (March 10, 2004). People show their pride in recognizable ways. UC Davis. Retrieved from https://www.ucdavis.edu/news/people-show-theirpride-recognizable-ways/.

Sara, M. (2010). Tenun ikat Timor simbol multikulturalisme. Detiknews.com. Retrieved from https://news.detik.com/opini/d-1472994/tenun-ikat-timor- simbol -multikulturalissme

Saraswati, D.P. (2010, October 20). Cangkang kerang yang memberi untung gilagilaan. Kontan.co.id. Retrieved from https://peluangusaha.kontan.co.id/news/ cangkang-kerang-yang-memberi-untung-gila-gilaan-1

Schroeder, J., Risen, J., Gino, F., Norton, M. I. (2014, May 14). Handshaking promotes cooperative dealmaking. Harvard Business School. Retrieved from https://www.hbs. edu/faculty/ Publication\%20Files/14-117_73032e86-d4d7-4b4b-ad5d5253e926853a. pdf

Stebbins, R. A. (1997). Casual leisure: A conceptual statement. Leisure Studies, 16(1), 17-25.

Steiner, R. (1911). The hidden depths of soul life. Rudolf Steiner Archive \& e.Lib. Retrieved from https://wn.rsarchive.org/GA/GA0061/19111123p01.html

Suleman, D.A. (2017). Batik as the crystallization of cultural elements. Proceeding of 2nd International Conference of Arts Language And Culture. Retrieved from https://jurnal.uns.ac.id/icalc/article/view/16178/13016

Taqwa, B.P. Sarung Tenun ATBM (Alat Tenun Bukan Mesin) di desa wanarejan utara kabupaten pemalang: kajian aspek motif dan proses produksi. Universitas Negeri Semarang. Retrieved from https://lib.unnes.ac.id/21537/1/2401410065-s.pdf

Thompson, I.J. (2002, February). Spiritual meaning of blue. Bible meanings. Retrieved from biblemeanings.info/Words/Colour/Blue.htm

Trisakti, F.A., Alfahmi, H. (March, 2018). Destination brand storytelling: narrative analysis of The Ministry of Tourism's "The Journey to A Wonderful World" video. Jurnal Komunikasi Indonesia, 7(1).

UNESCO Intangible Cultural Heritage. (n.d). Indonesian Batik. United Nations Educational, Scientific and Cultural Organization. Retrieved from https://ich.unesco.org/en/RL/indonesian-batik-00170 
UNESCO World's Heritage Center. (n.d). Cultural landscape of Bali Province: the Subak system as a manifestation of the Tri hita kirana philosophy. United Nations Educational, Scientific and Cultural Organization. Retrieved from https://whc.unesco.org/en/list/1194/

UNESCO World's Heritage Center. (n.d). Komodo National Park. United Nations Educational, Scientific and Cultural Organization Retrieved from https://whc.unesco.org/en/list/609

Verma, R. (2014). Social significance of color. International Journal of Research.

Retrieved from http://granthaalayah.com/Composition of colours/Articles/153 IJRG14 CC11 171.pdf

Waworuntu, M. (n.d). Indonesian batik: Identity, symbolism and textile communication. Academia.edu. Retrieved from https://www.academia.edu/14948401/Indonesia

Widiastuti, R., Nurtaanzila, L. (2018, September). Membaca citra Indonesia dalam arsip audio visual Kementerian Pariwisata. Diplomatika 2(1),44-53

Willis, O. (2018). Surf therapy offering hope, healing and a different approach to mental health treatment. $A B C$ Health and Wellbeing. Retrieved from https://www.abc .net.au/ health/2018-11-27/surf-therapy-offering-a-different-mental-health approach/ 10549952

Zaltman, G., Zaltman, L.H. (2008). Marketing metaphoria: what deep metaphors reveal about the minds of consumers. Massachusetts: Harvard Business Press.

Zimmerman, T. (2011). A feminist aesthetics of nature. Rupkatha Journal on Interdisciplinary Studies in Humanities, 3(1). Retrieved from http://rupkatha.com/V3/n1 /16A-Feminist-Aesthetics-of-Nature.pdf 